Brit. J. industr. Med., 1951, 8, 68.

\title{
THE ACTION OF SMALL AMOUNTS OF QUARTZ AND LARGER AMOUNTS OF COAL AND GRAPHITE ON THE LUNGS OF RATS
}

\author{
BY \\ S. C. RAY, E. J. KING, and C. V. HARRISON \\ From the Postgraduate Medical School, London
}

(RECEIVED FOR PUBLICATION OCTOBER 26, 1950)

Experimental and field work on silicosis, while concentrating attention on the danger of exposure to the dust from hard rock, has produced a sense of false security in regard to the coal miner. Mavrogordato (1918) stated: "It may be regarded as established that all forms of dust enter the lungs and that some, such as coal, are relatively harmless, while others, such as flint, are deadly". Bronchitis and emphysema were prevalent among old miners, but, as colliers were thought to be relatively immune to tuberculosis, it was assumed that inhalation of coal dust did not produce silicosis (Oliver, 1909 ; Collis, 1915; Haldane, 1931). Coal dust, as a result of experimental study, was not only claimed to be exempt from blame, but even came to be regarded as a beneficent agent capable of neutralizing the harmful effects of silica. Tattersall (1926) reported cases of silicosis among hard ground workers in coal mines, and Jousset (1928) attributed to silicosis the most important place in the production of "black lung" of coal miners. $\mathrm{He}$ also found by analysis that the silica content was 10 to 20 times more in the sclerosed lungs than in the normal ones. Policard and Devuns (1930), by a special microscopic technique, came to the conclusion that pulmonary anthracosis and fibrosis of the lungs of coal miners were merely two phases of the same process. Cummins (1927) advanced the hypothesis that silicosis, by causing interference with the lymph drainage of the lungs, led to the retention and accumulation of coal dust in the pulmonary tissues. Belt and King (1945) found in their experimental study that purest coal dust, whether anthracite or bituminous, had a low pathogenicity and caused only minimal fibrosis, but although results were not clear cut, there was some evidence that the pathogenicity increased with the increase of siliceous matter in the coal. Gough (1947) wrote :

"It has now been generally acknowledged that chronic respiratory disease of South Wales coal miners is due to the inhalation of the dust encountered in everyday work in the mines or in such an occupation as loading coal in ships."

He also stated :

"It is recognized that dust of relatively low silica content, such as commercial cual, can cause disability and fatal lung disease."

This disease was termed " coal workers' pneumoconiosis" by the Industrial Pulmonary Diseases Committee (1942) to distinguish it from classical silicosis, which may occur in those coal miners exposed to the dust of highly siliceous rocks.

In the coal industry the amount of siliceous matter inhaled varies according to the work of the miner and the part of the mine in which he is employed. Dust derived from the strata above the coal measure contains much silica; at the coal face it consists of coal mixed with some siliceous matter, while the dust breathed by coal trimmers is composed mainly of coal.

In view of these different opinions about the pneumoconiosis of coal miners, and in order better to understand the mechanism of its production, animal experiments with mixtures of coal and silica were undertaken. King, Harrison, and Ray (1949) found that 5 and $10 \mathrm{mg}$. of quartz with 95 and $90 \mathrm{mg}$. of anthracite coal produced rather more and larger nodules, and the nodules contained more reticulin fibres than those that could be produced with 5 and $10 \mathrm{mg}$. of quartz alone. But the contrast was not always clear-cut. With most rats $5 \mathrm{mg}$. of quartz appeared to be cleared from the lungs into the lymph nodes, and likewise with several 
receiving $10 \mathrm{mg}$. These animals failed to develop fibrous nodules in the lung tissue. The remainder, however, did not succeed in getting rid of their administered quartz; and the lesions which developed in their lungs were not much less severe than those in the rats which received the same amount of quartz with, in addition, $90 \mathrm{mg}$. of coal. Therefore, it was thought worthwhile to test again the tissue reactions to clean coal (anthracite with very little ash), and the same clean coal with a smaller amount $(2 \mathrm{mg}$.) of quartz.

In the preceding paper it has been shown that $2 \mathrm{mg}$. of quartz is regularly cleared from rat's lungs into the lymph nodes, while with 5 and $10 \mathrm{mg}$. doses sufficient remains to produce fibrosis.

Graphite has been tested in the same way. Graphite is widely distributed. in nature, and is generally found mixed with quartz (Milner, 1940). It is doubtful if pure natural graphite can be obtained commercially. Dassanayake (1948) pointed out that it is mined from vertical lodes in granite rock. According to Strong (1945) it contains 50 to $97 \%$ of carbon in natural form. Dunner and Bagnall (1946) gave the following figures for powdered commercial graphite : loss on ignition (mainly carbon) $52.7 \%$, total silica $25.1 \%$, and soluble silica $0 \cdot 26 \%$. A crystalline form of graphite known as "kish" is deposited in iron furnaces from molten iron on cooling.

Graphite is an important article of commerce, and in many industrial processes there is a risk of inhalation of its particles. Dunner (1945) recorded five cases of exposure to "pure graphite dust". Radiographs showed reticulation and nodulation. Dunner and Bagnall (1946) and Dunner (1948) reported a form of "snowstorm" appearance which became nodulated, and one case had a cavity. Gloyne, Marshall, and Hoyle (1949) described two cases of fatal pneumoconiosis caused by mixed dusts containing graphite, free silica, and certain silicates. In both there was progressive massive fibrosis, superimposed on dust reticulation. Harding and Oliver (1949) stated that graphite pneumoconiosis was a modified form of silicosis, and was caused by inhalation of dust composed largely of carbonaceous material with an amount of free silica of the order of $10 \%$.

In our experiments specially prepared graphite of very low ash content was used. In experiments with graphite and quartz, the latter was the same as that previously used in the coal experiment. The size distribution, and other analyses, of the minerals used are given in Table 1.

The anthracite was powdered in an agate mortar, and was unfortunately not as fine as we should have liked. Only about $14 \%$ (by mass) was sufficiently
TABLE 1

SIZE DISTRIBUTION AND ANALYSIS OF MINERALS

\begin{tabular}{|c|c|c|c|}
\hline \multicolumn{2}{|c|}{$\begin{array}{c}\text { Size Group } \\
(\mu)\end{array}$} & $\begin{array}{c}\text { Percentage by } \\
\text { Number } \\
\text { (cumulative) }\end{array}$ & $\begin{array}{c}\text { Percentage by } \\
\text { Mass } \\
\text { (cumulative) }\end{array}$ \\
\hline \multicolumn{4}{|c|}{ Anthracite $A_{3}$ Clean Coal } \\
\hline $\begin{array}{l}\text { Under } \\
\text { ", } \\
", \\
", \\
", \\
" \\
" \\
\text { " }\end{array}$ & $\begin{array}{l}0.5 \\
1.0 \\
2.0 \\
3.0 \\
4.0 \\
5.0 \\
6.25 \\
7.5 \\
10.0 \\
12.5 \\
25.0\end{array}$ & $\begin{array}{r}29 \cdot 5 \\
56 \cdot 6 \\
71 \cdot 5 \\
82.5 \\
88 \cdot 5 \\
92 \cdot 5 \\
95 \cdot 0 \\
97 \cdot 0 \\
98 \cdot 0 \\
99 \cdot 5 \\
100 \cdot 0\end{array}$ & $\begin{array}{r}0.03 \\
0 \cdot 26 \\
0 \cdot 83 \\
2 \cdot 0 \\
3 \cdot 4 \\
5 \cdot 1 \\
6 \cdot 9 \\
10 \cdot 2 \\
13 \cdot 9 \\
34 \cdot 6 \\
100 \cdot 0\end{array}$ \\
\hline
\end{tabular}

Mean particle size : by number 0.88 , by mass $19.5 \mu$. Ash : $0.9 \%$. Silica : $0 \cdot 2 \%$.

\begin{tabular}{|c|c|c|c|}
\hline \multicolumn{4}{|c|}{ Graphite } \\
\hline Under & 0.5 & $19 \cdot 0$ & $0 \cdot 103$ \\
\hline , & $1 \cdot 0$ & $38 \cdot 0$ & 0.93 \\
\hline , & $2 \cdot 0$ & $68 \cdot 8$ & $7 \cdot 12$ \\
\hline ,, & 3.0 & $82 \cdot 0$ & $14 \cdot 45$ \\
\hline , & $4 \cdot 0$ & 89.0 & $22 \cdot 66$ \\
\hline , & $5 \cdot 0$ & $94 \cdot 3$ & $34 \cdot 72$ \\
\hline ", & $6 \cdot 25$ & $97 \cdot 0$ & 45.04 \\
\hline ," & $7 \cdot 5$ & $98 \cdot 5$ & $57 \cdot 99$ \\
\hline . & $10 \cdot 0$ & $99 \cdot 8$ & $81 \cdot 97$ \\
\hline . & $12 \cdot 5$ & $100 \cdot 0$ & $100 \cdot 0$ \\
\hline & 25 & & \\
\hline
\end{tabular}

Mean particle size : by number $1 \cdot 3$, by mass $6.9 \mu$. Ash : $0 \cdot 72 \%$. Silica : $0 \cdot 24 \%$.

\begin{tabular}{|c|c|c|c|}
\hline \multirow[b]{2}{*}{ Under } & \multicolumn{3}{|c|}{ Commercial Quartz } \\
\hline & $0 \cdot 25$ & $7 \cdot 7$ & \\
\hline „, & $0 \cdot 5$ & $28 \cdot 9$ & $\cdot 8$ \\
\hline & $1 \cdot 0$ & $67 \cdot 1$ & $12 \cdot 0$ \\
\hline & $1 \cdot 5$ & $83 \cdot 6$ & $20 \cdot 0$ \\
\hline 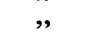 & $2 \cdot 0$ & $91 \cdot 9$ & $31 \cdot 0$ \\
\hline 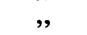 & $3 \cdot 0$ & $98 \cdot 0$ & \\
\hline 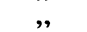 & $4 \cdot 0$ & 99.0 & $52 \cdot 0$ \\
\hline , & $5 \cdot 0$ & 99.5 & $70 \cdot 0$ \\
\hline
\end{tabular}

Mean particle size : by number $0 \cdot 8$, by mass $2 \cdot 8 \mu$. Silica : $97.1 \%$; solubility $3.4 \mathrm{mg} . / 100 \mathrm{ml}$.

small to be likely to be able to enter the lungs by inhalation; and if these experiments are repeated by a dusting technique it will be necessary to devise a method whereby the coal can be reduced to smaller dimensions. The graphite, on the other hand, was specially prepared in a " turbine grinder" and was $80 \%$ of respirable size, while the quartz was all sufficiently small to enter the lungs by inhalation.

\section{Method}

The animal experiments were conducted along the lines described in our preceding paper. The technique was that of Kettle and Hilton (1932) as modified by Belt and King (1945). Black and white rats of $200 \mathrm{~g}$. 
weight were lightly anaesthetized with ether and the trachea exposed by dissection. Suspensions in normal saline of pure coal, coal and quartz, graphite, and graphite and quartz were injected intratracheally into the lungs of rats. Each rat was given $1.5 \mathrm{ml}$. of the suspension, which contained $100 \mathrm{mg}$. of coal, $98 \mathrm{mg}$. coal $+2 \mathrm{mg}$. quartz, $100 \mathrm{mg}$. graphite, or $98 \mathrm{mg}$. of graphite $+2 \mathrm{mg}$. of quartz. For the coal experiment 32 rats were used, 16 in each group, and 40 rats for the graphite experiment, 20 in each group. The rats died or were killed at regular intervals up to 327 days. The lungs of a few rats were lost through cannibalism.

Pathological Technique.-The lungs were removed after insufflation with formol saline through the trachea. Fixation, embedding, and sectioning were carried out as in the experiments already reported. Routine sections

TABLE 2

ASSESSMENT OF FIBROSIS IN SECTIONS OF LUNGS

\begin{tabular}{|c|c|c|c|}
\hline \multicolumn{2}{|c|}{ Clean Coal (100 mg.) } & \multicolumn{2}{|c|}{$\begin{array}{l}\text { Clean Coal (98 mg.) } \\
\text { + Quartz (2 mg.) }\end{array}$} \\
\hline $\begin{array}{l}\text { Days of } \\
\text { Survival }\end{array}$ & $\begin{array}{l}\text { Grade of } \\
\text { Fibrosis }\end{array}$ & $\begin{array}{l}\text { Days of } \\
\text { Survival }\end{array}$ & $\begin{array}{c}\text { Grade of } \\
\text { Fibrosis }\end{array}$ \\
\hline 9 & 0 & 23 & 0 \\
\hline- & - & 27 & 0 \\
\hline- & - & 31 & 0 \\
\hline- & 一 & 63 & 1 \\
\hline$\overline{116}$ & $\overline{0}$ & 92 & 1 \\
\hline $\begin{array}{l}116 \\
126\end{array}$ & $\begin{array}{l}0 \\
0\end{array}$ & 101 & 1 \\
\hline 147 & 0 & - & E \\
\hline 157 & 0 & 153 & 2 \\
\hline 169 & 0 & $\overline{102}$ & $\sqrt{2}$ \\
\hline 186 & $\stackrel{1}{\text { (minimal) }}$ & 183 & 2 \\
\hline $\begin{array}{l}189 \\
200\end{array}$ & 1 (minimal) & $\begin{array}{l}197 \\
217\end{array}$ & $\begin{array}{l}2 \\
2\end{array}$ \\
\hline- & - & 247 & 3 \\
\hline - & - & 257 & 3 \\
\hline- & - & 285 & 3 \\
\hline 305 & 1 & 292 & 3 \\
\hline \multicolumn{2}{|c|}{$\begin{array}{l}\text { Pure Graphite } \\
\text { (Turbine Ground) } \\
\text { (98 mg.) }\end{array}$} & \multicolumn{2}{|c|}{$\begin{array}{c}\text { Pure Graphite } \\
\text { (Turbine Ground) } \\
\text { (98 mg.) }+ \text { Quartz (2 mg.) }\end{array}$} \\
\hline 11 & 0 & 21 & 0 \\
\hline 39 & 0 & 22 & 0 \\
\hline 44 & 0 & 22 & 0 \\
\hline$\overline{63}$ & $\overline{0}$ & $\begin{array}{l}52 \\
53\end{array}$ & 1 \\
\hline 78 & 1 & 66 & 1 \\
\hline 100 & 1 & 92 & 1 \\
\hline 109 & 1 & $\overline{10}$ & - \\
\hline 111 & 1 & 112 & 1 \\
\hline 171 & 1 & 171 & $\overline{2}$ \\
\hline 188 & 1 & - & - \\
\hline 191 & 1 & - & - \\
\hline 226 & 1 & 226 & 2 \\
\hline $\begin{array}{l}244 \\
285\end{array}$ & $\begin{array}{l}1 \\
1\end{array}$ & 251 & $\underline{2}$ \\
\hline 316 & 1 & - & - \\
\hline 327 & 1 & 327 & 2 \\
\hline
\end{tabular}

across the middle of both lungs including the hilar lymph glands were cut in all cases, and stained with haematoxylin and eosin and Gordon and Sweets' (1936) silver impregnation method for reticulin.

\section{Pathological Findings}

Clean Coal (100 mg.). - On the ninth day coal was seen in coarse aggregates in groups of alveoli, and some was found in the root glands. A similar picture was seen on the 116th day. On the 126th day coal aggregates were again found, and there was some in the interstitial tissue, but no fibrosis. Lungs removed from rats on the 147th day and 157 th day showed a similar picture. On the 169th day coal particles were seen in the interstitial tissue, and were just beginning to be walled-off. On the 186th and 189th days the walling-off effect of coal became distinct, but the reticulinosis still remained minimal.

Coal particles were seen enmeshed in very fine reticulin fibres at 200 and 305 days. This type of fibrosis is minimal, and we have called it Grade 1 (Fig. 1).

It was noticeable that the amount of coal in the lung parenchyma of rats killed later in the experiment was much less than in those killed earlier. This is likely to be due to elimination into the glands.

Coal (98 mg.) + Quartz (2 mg.).-In contrast to the pure coal experiment, peribronchial and perivascular reactions were noticeable as early as the 27th day. Coal particles were found enmeshed in reticulin fibrils of Grade 1 severity on the 63rd day. This picture persisted till the 101st day. From the 101 st to 217th days the degree of fibrosis changed in character to Grade 2. In lungs examined from the 247 th to the 292nd day the reticulin fibres became more compact and collagenous, and assumed the character of Grade 3 fibrosis (Fig. 2).

Distribution of Dust.- There was no recognizable difference in the localization of dust between the two experiments. In the early stages the dust was indifferently scattered through the alveoli. Later on, it became localized in both experiments in the vicinity of the alveolar ducts.

Graphite (100 mg.).-The histological pattern resembled that described with pure coal. The distribution was scattered, and organization was of the foreign-body type. Sections from lungs on the 11 th, 39th, and 44th days showed practically no reaction. Fine reticulin fibrils enmeshing the graphite particles were first seen in the section of the lung on the 78th day. The fibrosis was of Grade 1 type. Sections from lungs from the 100th to the 327th day, at various intervals, showed that the grade of fibrosis remained the same throughout (Fig. 3). 


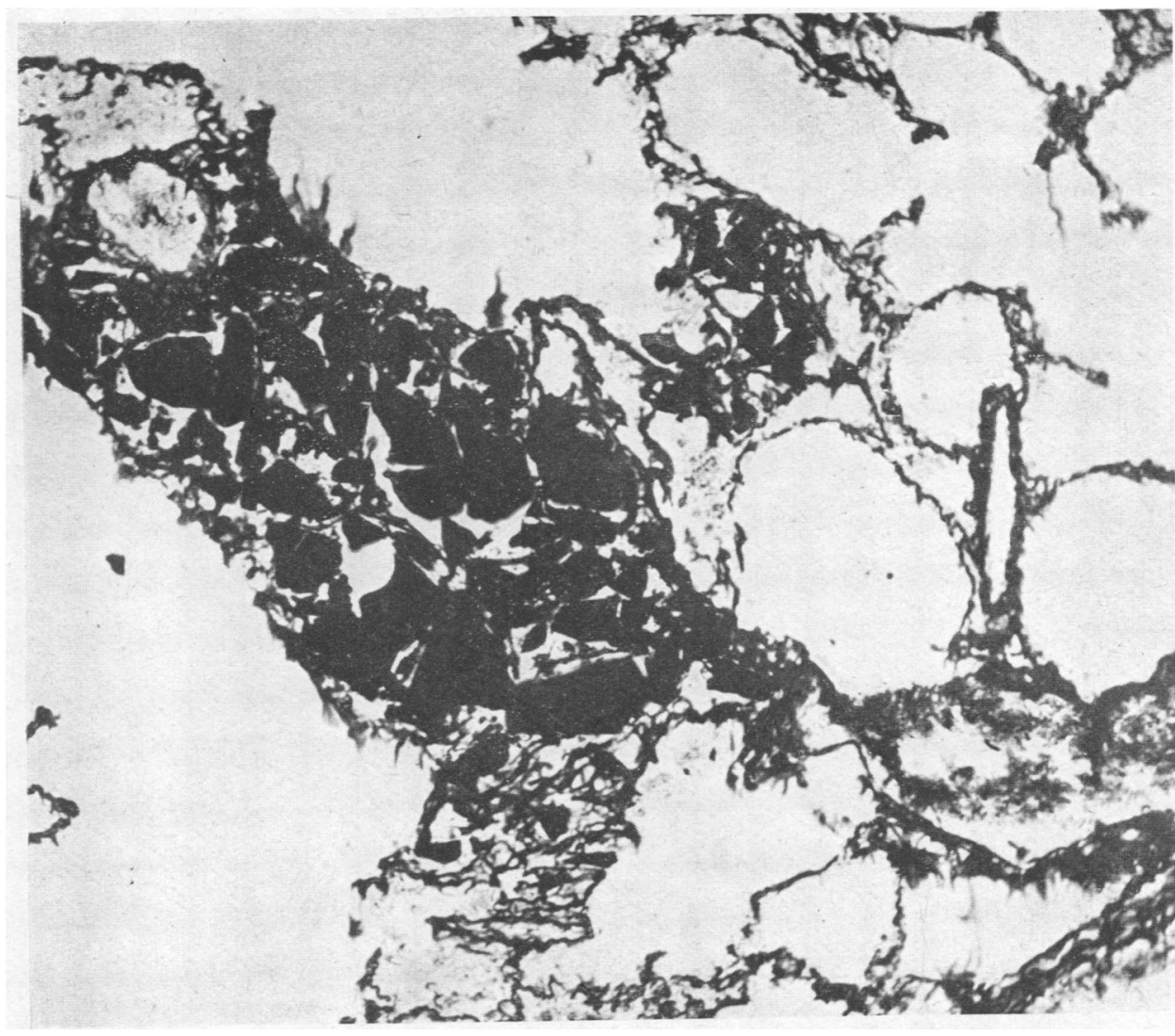

FIG. 1.-Rat lung 305 days after a dose of $100 \mathrm{mg}$. of pure coal. The coal particles are collected into a small focus and enmeshed by a minimal quantity of fine reticulin fibrils (silver impregnation $\times 190$ ).

Fig. 2.-Rat lung 292 days after a dose of $98 \mathrm{mg}$. of coal plus $2 \mathrm{mg}$. of quartz. Compared with Fig. 1 there is considerably more reticulin production (silver impregnation $\times 190$ ).

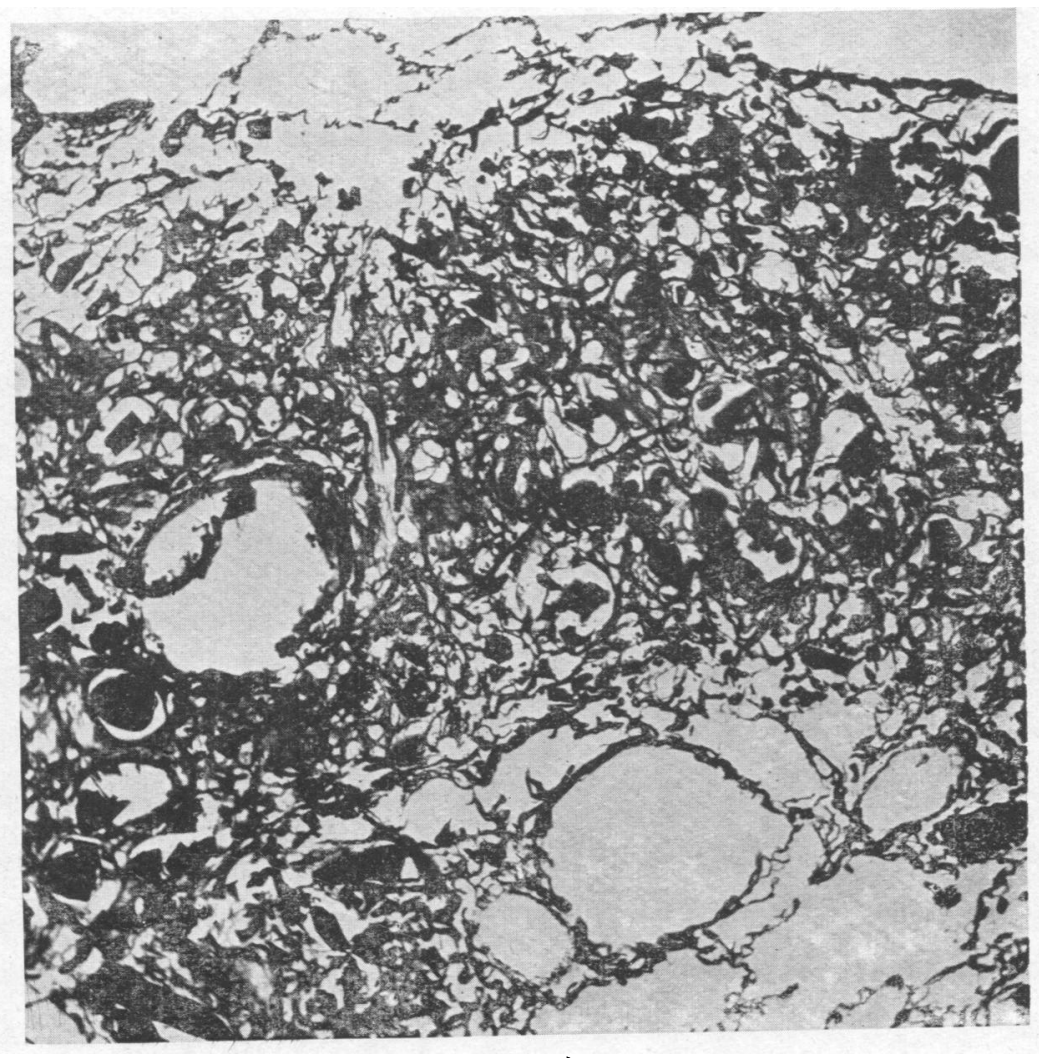


Fig. 3.-Rat lung 327 days after a dose of $100 \mathrm{mg}$. of graphite. The graphite is enmeshed in a minimal quantity of reticulin fibrils, the lesion being exactly similar to that produced by coal (Fig. 1) (silver impregnation $\times 190$ ).
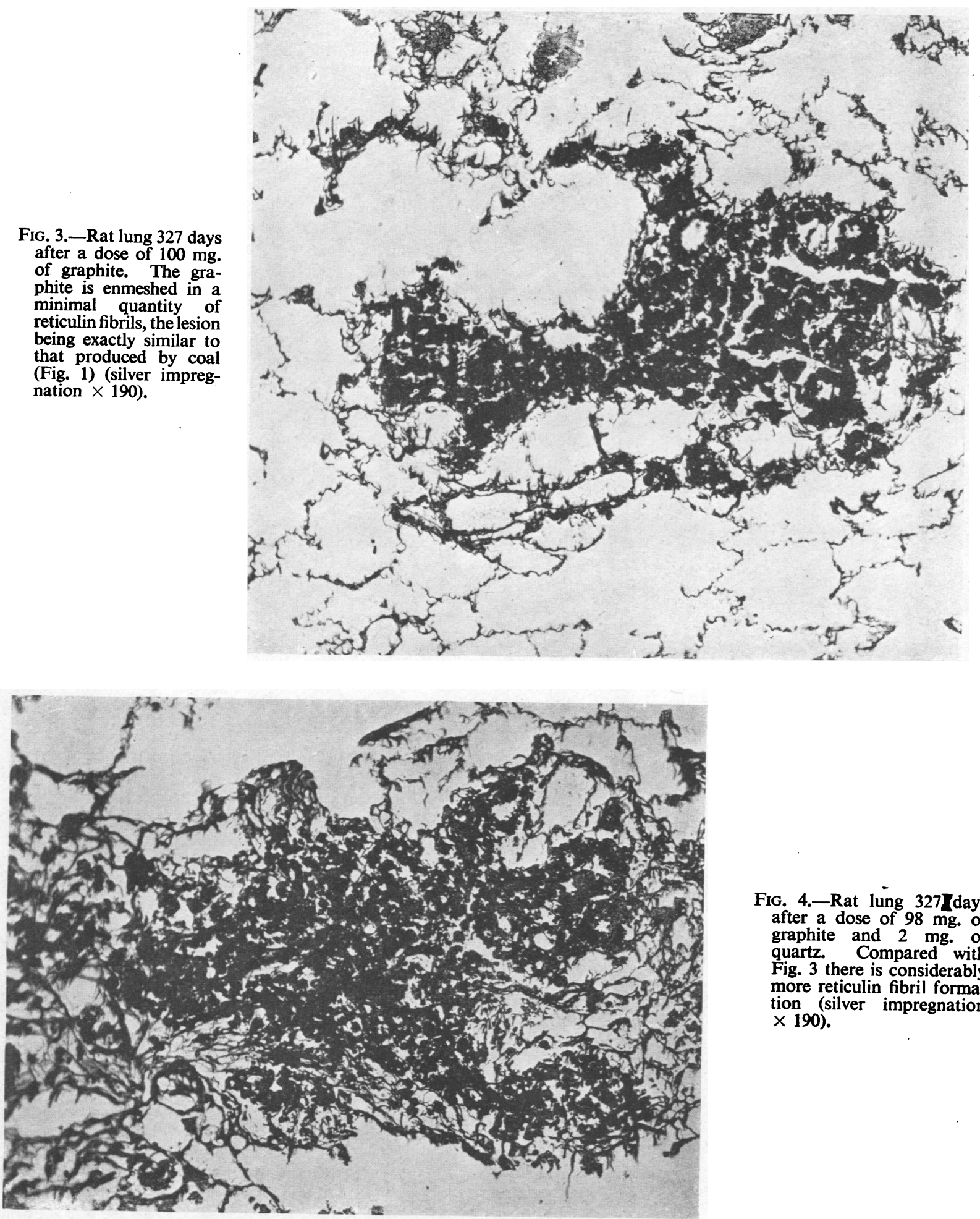

Fig. 4.-Rat lung 327/days after a dose of $98 \mathrm{mg}$. of graphite and $2 \mathrm{mg}$. of quartz. Compared with Fig. 3 there is considerably more reticulin fibril formation (silver impregnation $\times 190$ ). 
Graphite (98 mg.) + Quartz (2 mg.).-Grade 1 fibrosis was seen on the 52nd day. This grade of fibrosis continued till 112 days. From the 171st day onwards the degree of fibrosis changed to Grade 2 and remained so till the 327th day (Fig. 4).

\section{Discussion}

It is generally accepted that silica itself is the cause of silicosis; but the question arises as to how far non-siliceous dusts assist or retard the silicotic process, when inhaled with silica. Hollmann (1937), Böhme and Lucanus (1930) and others have concluded that pure dusts like coal and iron can be responsible for serious pneumoconiosis, as lesions produced by these dusts resemble in some respects those of silicosis. Similar observations have been made by Bergstrand (1930) and Frimann-Dahl (1937).

The effect of coal dust has been studied before, especially with reference to its power to increase phagocytosis of siliceous dusts, or to absorb the silica released in solution from such dusts. From such studies it had been concluded that inhalation of coal dust should lessen the pathogenicity of siliceous dusts (Carleton, 1924; Haldane, 1929 ; Whitehouse, 1938); indeed, many have believed that coal dust protects against silicosis. Sayers, Meriwether, Lanza, and Adams (1933), on the other hand, reported cases of acute silicosis from the inhalation of coal dust, and they thought the coal probably hastened the action of the silica. Policard and other French authors have noted that the lymphatics of the lung become blocked by the dust.

In this experiment we have not been able to produce any serious reaction to coal over a period of 300 days.

It has been shown in our preceding experiments with $2 \mathrm{mg}$. of silica (Ray, King, and Harrison, page 63) that this amount is almost entirely eliminated from the lung parenchyma via the lymphatics, but causes fibrosis of the hilar glands and some degree of peribronchial or perivascular fibrosis. When coal is added to this small amount of quartz, the lymphatic drainage is presumably blocked, and silica remains in the lung parenchyma. As a result the retained silica exerts its toxic effect there with the ultimate production of fibrous nodules. This appears to be the most reasonable interpretation of our results.

Pure graphite has been found to be as inert as pure coal, and exhibits no more pathogenicity in the lung than pure coal. From both these experiments it has been concluded that it is the retained silica which is pathogenic and causes the fibrous lesions in the lungs, and that the simultaneous presence of large amounts of coal or graphite exaggerates the pathogenic effect of small amounts of silica.

\section{Summary}

The part played by clean coal and pure graphite in the production of experimental silicosis has been studied.

Pure coal gives rise to no serious reaction in the animal lungs. Much of it is eliminated, and the amount retained causes only slight reticulinosis.

Small doses of quartz which alone produce no lesion in the rats' lungs, produce nodular foci of reticulinosis when large amounts of coal are added. The large amount of coal probably upsets the drainage mechanism, and the retained silica in the lung exerts its toxic effect with the production of fibrous nodules.

Pure graphite was as inert as pure coal; but fibrous nodules were produced when it was mixed with small amounts of silica. It is therefore concluded that the simultaneous presence of large amounts of coal or graphite exaggerated the pathogenic effects of small amounts of silica.

We are grateful to the Medical Research Council for a grant to defray the expenses of this investigation. Miss V. Pash, Mr. W. Weedon and Mr. B. C. S. Hollands rendered valuable technical assistance, and Mr. E. V. Willmott prepared the photomicrographs. Dr. B. M. Wright kindly obtained for us the specimen of pure graphite.

\section{REFERENCES}

Belt, T. H., and King, E. J. (1945). Spec. Rep. Ser. med. Res. Coun. Lond., No. 250, p. 29.

Bergstrand, H. (1930). Virch. Arch., 278, 647

Böhme, A., and Lucanus, C. (1930). Der Verlauf der Staublungenerkrankung bei den Gesteinshauern des Ruhrkohlengebietes. Berlin.

Carleton, H. M. (1924). J. Hyg., 22, 438.

Collis, E. L. (1915). Industrial Pneumonoconioses with Special Reference to Dust-Phthisis. Milroy Lecture. London : H.M.S.O. 1919. (Reprinted from 'Public Health'.)

Committee on Industrial Pulmonary Disease (1942). Spec. Rep. Ser. med. Res. Coun. Lond., No. 243, p. xi.

Cummins, S. L. (1927). J. Path. Bact., 30, 615.

Dassanayake, W. L. P. (1948). British Journal of Industrial Medicine, 5, 141 .

Dunner, L. (1945), Brit. J. Radiol., 18, 33.

1948). Ibid, 21, 182.

—, and Bagnall, D. J. T. (1946). Ibid, 19, 165

Frimann-Dahl, J. (1937). Norsk. Mag. Laegevidensk., 98, 273.

Gloyne, S. R., Marshall, G., and Hoyle, C. (1949). Thorax, 4, 31

Gordon, H., and Sweets, H. H., Jr. (1936). Amer. J. Path., 12, 545

Gordon, J. (1947). Occup. Med., 4, 86.

Haldane, J. S. (1929). Transvaal Chamber of Mines 40th Ann. Rep., 118 ; (1931) Trans. Inst. Mining Eng., 80, 415.

Harding, H. E., and Oliver, G. B. (1949). British Journal of Industrial Medicine, 6, 91 .

Hollmann, W. (1937). Röntgenpraxis, 9, 32.

Jousset, A. (1928). Rev. de la Tuberc., IX, 884.

Kettle, E. H., and Hilton, R. (1932). Lancet, 1, 1190.

King, E. J., Harrison, C. V., and Ray, S. C. (1949). Proc. 9th Internat. Congr. industr. Med., London, 1948, p. 666.

Mavrogordato, A. (1918). J. Hyg., Camb., 17, 439.

Milner, H. B. (1940). Sedimentary Petrography, 3rd Ed. London : Milner, H. B. (1940). Sediment

Oliver, T. (1909). In C. Allbutt and H. D. Rolleston's System of Medicine, vol. V, 462 . London.

Policard, A., and Devuns, J. (1930). C. R. Acad. Sci., Paris, 190, 979.

Sayers, R. R., Meriwether, F. V., Lanza, A. J., and Adams, W. W. (1933). U.S. Bureau of Mines, Technical Paper No. 545.

Strong, R. K. (1945), Kingzett's Chemical Encyclopaedia rev. by Strong, 7th Ed. London : Baillière, Tindall \& Cox.

Tattersall, N. (1926). J. industr. Hyg., 8, 466.

Whitehouse, A. G. R. (1938). Ibid. 20, 556. 